J. Product. \& Dev., 16(1):87 - 100 (2011)

\title{
In vitro ANTAGONISTIC ACTIONS OF HUMIC SUBSTANCE ON THE GROWTH OF Sclerotium rolfsii AND THE BIOCONTROL Trichoderma spp.
}

\section{H. A. Emmara*; M. F. Salem** and Heba. S. Abbas*}

* Plant Biotechnology Department, Genetic Engineering and Biotechnology Research Institute (GEBRI), P.O. Box, 79, Sadat City, Minufiya University, Egypt.

** Environmental Biotechnology Department, Genetic Engineering and Biotechnology Research Institute (GEBRI), P.O. Box, 79, Sadat City, Minufiya University, Egypt.

\section{ABSTRACT}

The effect of humic substance, isolated from a composting substrate, was evaluated on the mycelial growth of two strains of Sclerotium rolfsii and the antagonistic Trichoderma sp. two strains of $S$. rolfsii treated with humic substances, one strain isolated from tomato stems and the other isolated from the roots of sugar beet. In general, any $H S$ treatment significantly reduced the radial growth of the S. rolfsii mycelium in normal potato dextrose agar (PDA) medium enriched with humic acid compared to potato dextrose agar medium free from humic acid. However S. rolfsii which isolated from tomato stems showed resistance against the effect of humic acid after 4 and 9 days from inoculation due to the soil treatment many times with humic acid. Humic acid treatment was also able to alter the sclerotial production either by significantly reducing the number of viable germinating sclerotia or by almost increasing the number of sclerotia to double as a resistance mechanism towards the survival of S. rolfsii. Apparently, the extent of the inhibitory action was related to some chemical and functional properties of HS, such as the COOH group content and elemental composition. On the contrary the same HS treatment generally did not inhibit the growth of Trichoderma sp. This study showed no significant correlation between HS chemical properties and Trichoderma sp. However, it showed the inhibitory effect of Trichoderma sp. in presence of humic acid on two isolates of $S$. rolfsii with percentage of inhibitions $53.3 \%$ and $94.4 \%$.

Keywords: Humic acid, Compost, Sclerotium rolfsii, Trichoderma sp, Mycelial growth, Sclerotial formation, Phytopathogen, Fungal antagonist. 


\section{INTRODUCTION}

Fungal plant diseases are one of the major concerns to agricultural production. It has been estimated that total losses as a consequence of plant diseases reach $25 \%$ of the yield in western countries and almost $50 \%$ in developing countries. Of this, one third is due to fungal infections (Bowyer, 1999). So there is a pressing need to control fungal diseases that reduce the crop yield so as to ensure a steady and constant food supply to ever increasing world population. Conventional practice to overcome this problem has been the use of chemical fungicides which have adverse environmental effects causing health hazards to humans and other nontarget organisms, including beneficial life forms. Hence there is increasing concern towards the toxicity and biomagnification potential of these chemicals in agriculture.

A number of studies have demonstrated that the two main fractions of soil native humic substances (HS), i.e., humic acids (HA) and fulvic acids (FA), organic amendments and/or HS-like materials present in them, besides Influencing directly and indirectly plant biology are also able to control plant diseases caused by various soil-borne phytopathogenic fungi, especially in the rhizosphere compartment. Further, the investigation on the biological activity of these materials on antagonistic soil-borne fungi is of great interest, in that their contribution to biological control should be safeguarded. Very few information is reported in the literature on the suppressive effects of HS and HS-like fractions on phytopathogenic fungi and, to our knowledge, no information is reported on antagonistic soilborne fungi (Loffredo et al., 2007).

Sclerotium rolfsii Sacc. (Athelia rolfsii (Curzi) Tu \&Kimbrough) causes the disease known as southern blight in a wide variety of crops. Sclerotium rolfsii forms brownish sclerotia that can survive in soil for long periods, frequently tolerating biological and chemical degradation due to the presence of melanin in the outer membrane (Chet, 1975). Alternative treatments for control of plant diseases are needed (Abd-El-Kareem et al., 2006).

Bosah et al. (2010) studied the inhibitory effectiveness of test antagonist-Trichoderma. Trichoderma was identified as significantly and potentially effective antagonists against the pathogen known to be destructive to most agricultural crops.

The objectives of this work are to investigate the effects in vitro of HS samples on the mycelial growth and sclerotial formation of the phytopathogenic $S$. rolfsii and (ii) the mycelial growth of the antagonistic Trichoderma species. 


\section{MATERIALS AND METHODS}

\section{Fungal Isolates and Culture Maintenance}

Two strain of $S$. rolfsii isolated from two infected plant parts:

1- Stems of tomato plants (April 2006) that were cultivated in the second army farm, abo-swair Ismalia Governorate, Egypt.( soil treated many times with humic acid).

2- Roots of sugar beet (Beta vulgaris L.) showing symptoms of root-rot growers in agriculture research center, El-Gharbya Governorate, Egypt.

Infected plant materials were brought from the field and washed then cut into $5 \mathrm{~mm}$ segments including the advancing margins of infection. The segments were surface disinfected in $0.5 \%$ sodium hypochlorite solution for $5 \mathrm{~min}$ and rinsed in three changes of sterile water. The Segments were separately dried in between sheets of sterile filter Paper and plated (3 pieces per plate) on fresh potato dextrose agar (PDA) medium, and incubated for 7 days at $28^{\circ} \mathrm{C} \pm 1$. Pure cultures of the final isolates were maintained on PDA slants and kept in the refrigerator until required. This method described as Okereke \& Wokocha (2007). The antagonistic Trichoderma sp. was isolated from Pleurotus spent mushroom compost from (Mushroom Research Unit, Genetic Engineering and Biotechnology Research Institute (GEBRI), Menoufiya University, 2-mm PDA disks overgrown by mycelium of 5 days were collected from the outer periphery of a colony and transferred centrally in new plates, which were maintained on PDA Petri plates at $20^{\circ} \mathrm{C} \pm 1$ in the dark.

Notes: Sclerotium rolfsii that isolated from infected tomato plants will take No. 1. While Sclerotium rolfsii that isolated from infected sugar beet plants will take No. 2.

\section{Effect of humic acid on the radial mycelial growth of $S$. rolfsii and} Trichoderma sp.

The present study use a modified protocol from (Loffredo et al., 2008). An aqueous solution of PDA 4\% w/v were steam sterilized, cooled at about $55^{\circ} \mathrm{C}$ and then amended with Humic acid suspension (belonging to Canada Humic company) at concentrations of 0 (control only PDA), $0.6 \%(1 \mathrm{ml}$ of humic/150 ml of PDA media). The higher concentration value of humic substance content increases was observed by several authors after soil amendments with fresh or composted organic materials at the doses commonly applied (Pascual et al., 1999; Adani et al., 2006).The lower dose was cautiously considered more appropriate in experiments conducted in vitro. Each medium was poured in Petri plates and let to cool at room temperature and solidfy. Then the two isolates of Sclerotium rolfsii was inoculated in the center of the plate. Also the Trichoderma sp. was inoculated in the center of the plate. All the plates 
were kept in the incubator in dark at a constant temperature $20^{\circ} \mathrm{C} \pm 1$. The apparent morphology and radial growth of the mycelium were evaluated after 2 , 4, 9 days until the fungi reached approximately the border of the plate. The percentage of inhibition by humic acid in case of Trichoderma $s p$. was determined. The number of sclerotia of the two isolates of Sclerotium rolfsii was determined after 15 days.

\section{Inhibitory effect of both humic acids and Trichoderma sp. on the radial mycelial growth of $S$. rolfsii.}

The two isolates of Sclerotium rolfsii was inoculated on PDA mixed with Humic acids (Aqueous solution of PDA were steam sterilized, cooled at about $55^{\circ} \mathrm{C}$ and then added with Humic at concentrations of 0 (control only PDA) and $0.6 \%$ at the center of $90 \mathrm{~mm}$ diameter. A disc of Sclerotium rolfsii was inoculated toward a disc of Trichoderma sp. The inoculated plates were incubated at $28{ }^{\circ} \mathrm{C} \pm 1$ and were observed for inhibition or otherwise their growth after 9 days. The inhibition percentage was calculated using the following formula:

Inhibition Percentage $(\%)=\mathrm{A} 1-\mathrm{A} 2 / \mathrm{A} 1 \times 100$, Where, A1 is the diameter of pathogenic fungi in the control, and A2 is the diameter of pathogenic fungi during interaction with Trichoderma $\mathrm{sp}$.

\section{RESULTS AND DISCUSSION}

\section{Isolation of Sclerotium rolfsii}

Data in Table (1) show the persistence of Sclerotium rolfsii in tomato and sugar beet crops as its frequency reached $100 \%$ in tomato plants (the soil treated with high percentage of humic acid) and 60\% in sugar beet plants (Beta vulgaris L.). Also other soil pathogenic fungi like Fusarium oxysporum and Rhizoctonia solani persisted in sugar beet plants. It was observed that Sclerotium rolfsii is the cause of root rot in sugar beet plants which is a severe disease of beet as in Figure (1), where Symptoms appeared as poor top growth with wilting and the root was decayed by the fungus. Southern blight symptoms in tomato plants as in Figure (2) the first signs of infection dark brown lesions on the stem or just beneath the soil level then the leaves turned yellow and wilt. Sclerotium rolfsii is an economically important pathogen in warm, moist climate worldwide; causing disease on more than 500 species of plants including almost all the agricultural and horticultural crops (Aycock, 1966). The large number of sclerotia produced by S. rolfsii and their ability to persist in the soil for several years, as well as the profuse growth rate of the fungus make it well suited facultative parasite and a pathogen of major importance throughout the world (Punja, 1985). In that concern, Rolfs (1892) was the first who 
Table 1. Frequency of soil pathogenic fungi including Sclerotium rolfsii in different host plants.

\begin{tabular}{|c|c|c|c|c|}
\hline $\begin{array}{c}\text { Host plant } \\
\text { and location }\end{array}$ & $\begin{array}{c}\text { Sclerotium } \\
\text { rolfsii }\end{array}$ & $\begin{array}{c}\text { Frequency } \\
\text { of S. rolfsii }\end{array}$ & $\begin{array}{c}\text { Fusarium } \\
\text { oxysporum }\end{array}$ & $\begin{array}{c}\text { Rhizoctonia } \\
\text { solani }\end{array}$ \\
\hline $\begin{array}{c}\text { Tomato plant (second } \\
\text { army, Abo-swair,Ismalia } \\
\text { Governate in April } \\
\text { 2006) }\end{array}$ & + & $100 \%$ & 0 & 0 \\
\hline $\begin{array}{c}\text { Sugar beet(agriculture } \\
\text { research center, El- } \\
\text { Gharbya Governorate) }\end{array}$ & + & $60 \%$ & + & + \\
\hline
\end{tabular}

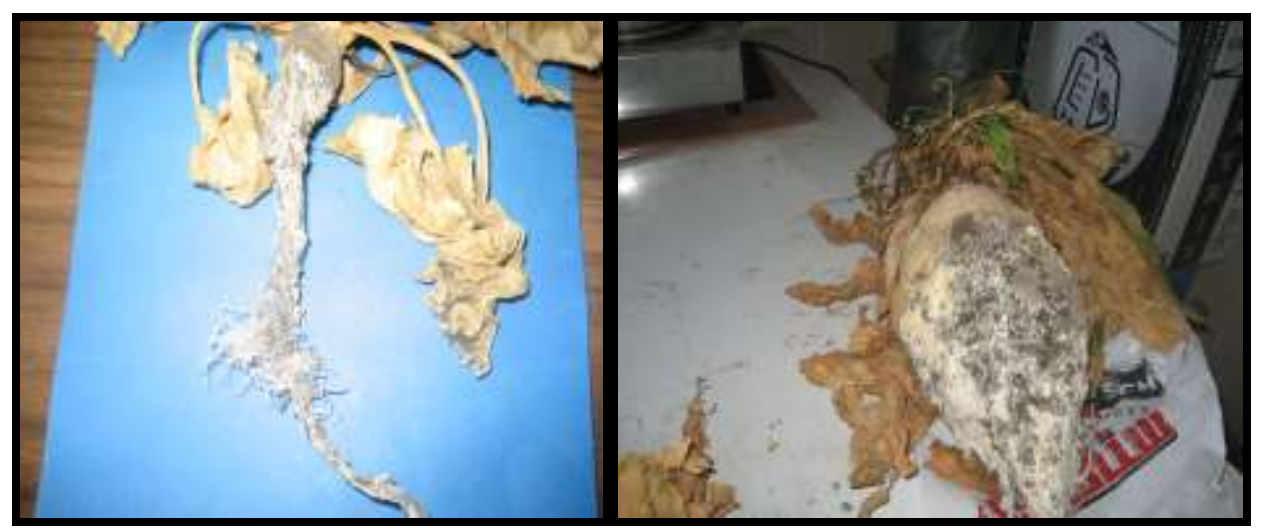

Figure 1. Root rots symptoms in sugar beet plants and a white mycelium of Sclerotium rolfsii.

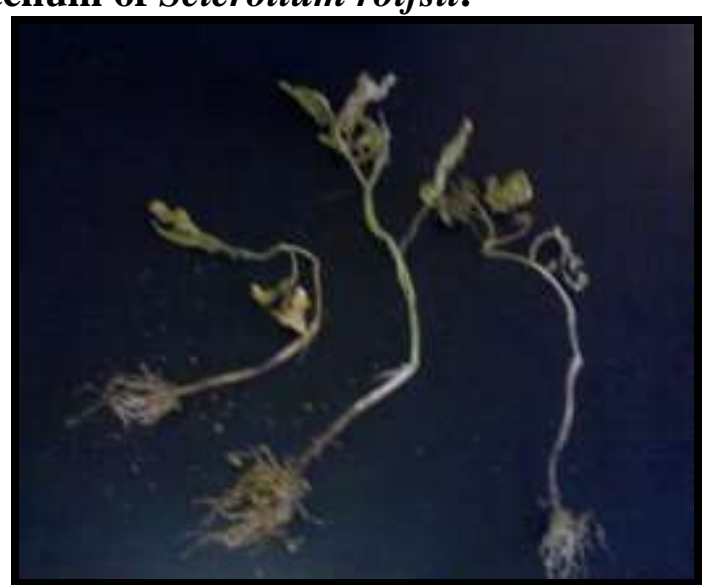

Figure 2. Yellowing and wilting leaves of tomato plants and a white mycelium of Sclerotium rolfsii. 
reported that Sclerotium rolfsii as a cause of tomato blight from Florida in U.S.A and cast iron plant by Mcmillan et al., (1998). An estimated loss of up to US\$ 10-20 million because of $S$. rolfsii has been reported in southern peanut growing region of USA with yield depletion ranging from 1-60\% in different fields (Aycock, 1966). Ahmed et al. (1984) made the first report of S. rolfsii from Pakistan on maize (Zea mays). The fungus was subsequently reported from oat (Avena sativa) and mash bean (Vigna mungo) by Shahzad \& Ghaffar (1995), apple (Malus sylvestris) by Jahangir et al. (1995), lentil (Lens culinaris) by Iqbal et al. (1995) and seed of sugarbeet (Beta vulgaris) by Ruqia (2001).

2. Effect of humic acid) on the radial mycelial growth of S. rolfsii and

\section{Trichoderma sp.}

2. 1. Effect of humic acid on the radial mycelial growth of $S$. rolfsii $(1,2)$ with respect to their control.

The effect of humic acid that was isolated from a composting substrate was evaluated on the mycelial growth of Sclerotium rolfsii. In general, any HS treatment significantly reduced the radial growth of the $S$. rolfsii mycelium in normal potato dextrose agar (PDA) medium enriched with humic acid $(0.6 \%)$ compared with potato dextrose agar medium free from humic acid. It was clear that, there is a contrast on the effects of this humic acid on the two tested $S$. rolfsii $(1,2)$. The first isolate $S$. rolfsii (1) was resistant to the effect of humic acid $(0.6 \%)$ after 4 and 9 days from inoculation. On the other hand, the second isolate was inhibited with a large extent as after 2, 4 and 9 days from inoculation as in Figures (3 and 4).
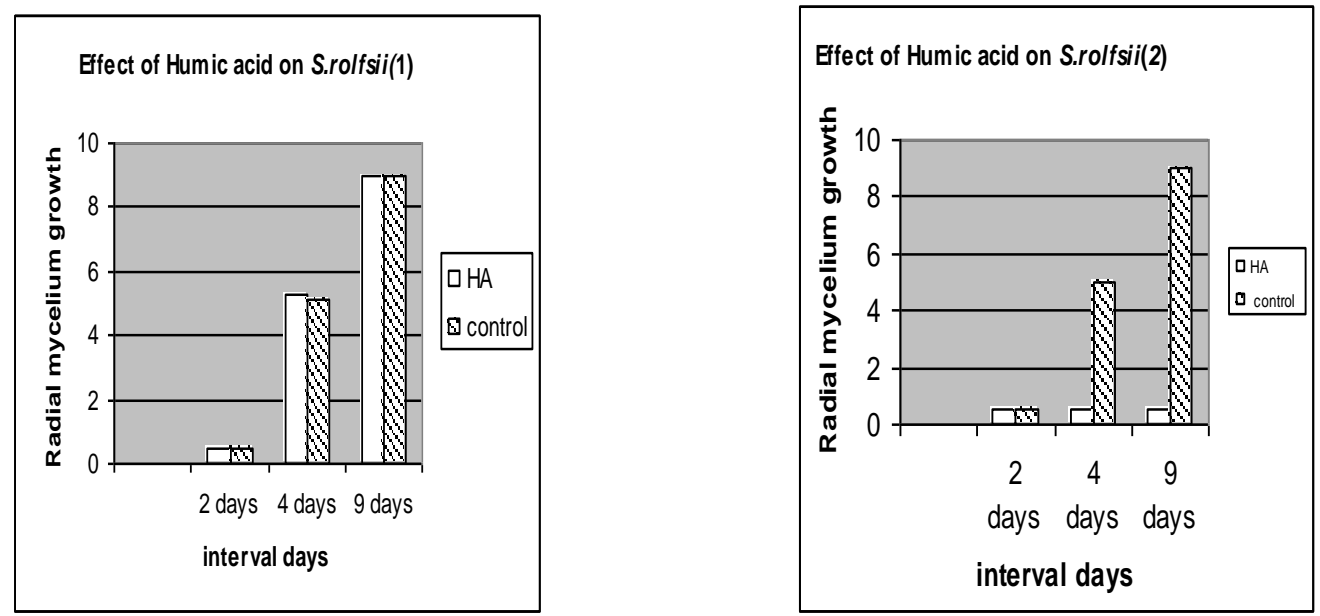

Figure 3. Effect of humic acid $(0.6 \%)$ on the radial mycelial growth of the two isolate of $S$. rolfsii (white bar) with respect to their control (dash bar). 

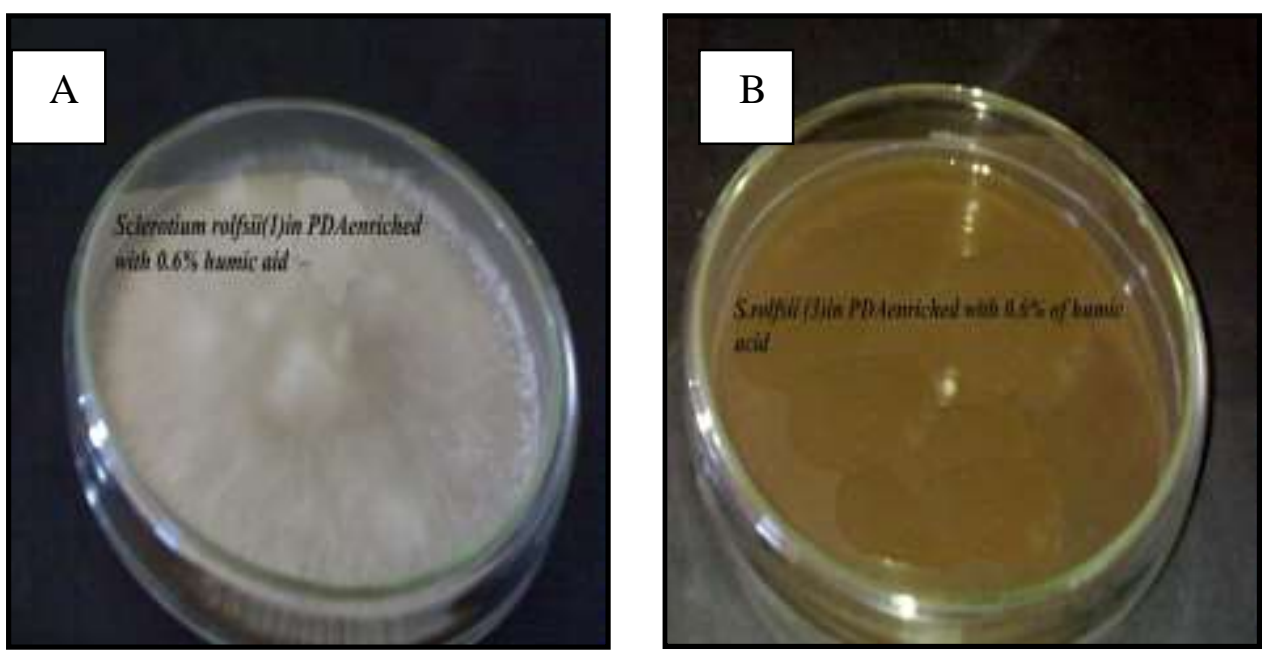

Figure 4. (A) Effect of humic acid $(0.6 \%)$ on the radial mycelial growth of $S$. rolfsii (Isolate1), (B) Effect of humic acid $(0.6 \%)$ on the radial mycelial growth of $S$. rolfsii (Isolate 2) after 9 days.

\section{2. Effect of humic acid on sclerotial formation of $S$. rolfsii}

Humic acid treatment was also able to alter the sclerotial production by reducing significantly the number of viable germinating sclerotia. Data in Table (2) show that humic acid at concentration $0.6 \%$ inhibited completely the production of sclerotia by Sclerotium rolfsii (2) compared with the control treatment. On the other hand, there was another attitude of the S. rolfsii (1) which was enhanced by the same concentration of the tested humic acid as in Figure 5.We have to notice that the sclerotial production was increased up to almost double as a resistance mechanism towards the survival of the causal organism.

Table 2. Effect of humic acid on sclerotial formation of $S$. rolfsii $(1,2)$ after 15 days.

\begin{tabular}{|c|c|c|}
\hline \multirow{2}{*}{$\begin{array}{c}\text { strains of } \\
\text { pathogenic } \\
\text { fungi }\end{array}$} & Control & HA \\
\cline { 2 - 3 } & 80 & 150 \\
\hline S. rolfsii (1) & 46 & 0 \\
\hline S.rolfsii (2) & & Sclerotia number \\
\hline
\end{tabular}




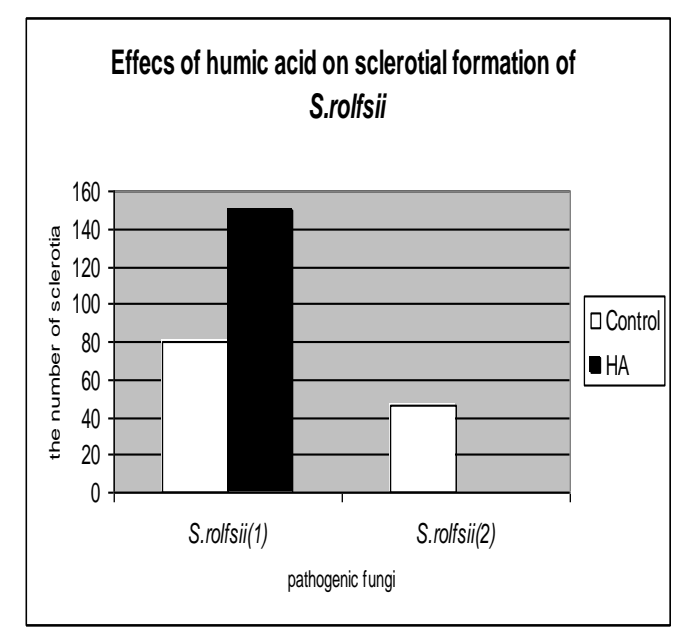

Figure 5. Effect of humic acid on the sclerotial formation of $S$. rolfsii (Isolate1 and Isolate 2) after 15 days.

In that concern, Loffredo et al. (2007) showed that The HS fractions isolated from the composting substrate were the most effective inhibitors of mycelial growth of Fusarium oxysporum $f$. sp. melonis (FOM) and $F$. oxysporum f. sp. lycopersici (FOL) and Furthermore, any HS treatment was also able to alter the germination process of FOL in aqueous medium, not only by reducing significantly the number of viable germinating conidia but also by generally decreasing the rate of conidial germ-tube elongation. The inhibitory action was related to some chemical and functional properties of HS, such as the $\mathrm{COOH}$ group content and elemental composition. In agreement with this study, Loffredo et al. (2008) showed the inhibitory action of HS especially those from composting substrates on mycelial growth of Sclerotium sclerotiorum and they related that to the small total carboxyl $\mathrm{COOH}$ group and $\mathrm{O}$ content and higher $\mathrm{H}$ content. Further, the number of sclerotia appeared to be positively influenced by the $\mathrm{N}$ content of HS (especially humic acid at high concentration).

\section{3. Effect of humic acid on Trichoderma sp.}

Data in Table (3) show slight morphological change in mycelial growth of Trichoderma $s p$. in the presence of humic acid at concentration $0.6 \%$. In presence of humic acid the growth of Trichoderma $s p$. decreased with percentage $27 \%$ after 9 days as in Figure 6. In agreement with this study, Loffredo et al. (2007) showed that HS treatment generally did not inhibit the growth of Trichoderma species and no significant correlation between HS chemical properties and HS activity was obtained in the case of Trichoderma species. 
Table 3. Effect of humic acid on the radial mycelial growth of Trichoderma sp.

\begin{tabular}{|c|c|c|c|}
\hline \multirow{2}{*}{$\begin{array}{c}\text { Interval } \\
\text { days }\end{array}$} & \multicolumn{3}{|c|}{ Radial mycelium growth of Trichoderma sp. (cm ) } \\
\cline { 2 - 4 } & $\begin{array}{c}\text { Humic } \\
\text { acid }\end{array}$ & $\begin{array}{c}\text { Control(zero } \\
\text { humic acid) }\end{array}$ & $\begin{array}{c}\text { Percentage of reduction } \\
(\%)\end{array}$ \\
\hline 2 days & 0.5 & 0.5 & zero \\
\hline 4 days & 5.3 & 7.5 & $29.3 \%$ \\
\hline 6 days & 6.5 & 9 & $27 \%$ \\
\hline
\end{tabular}

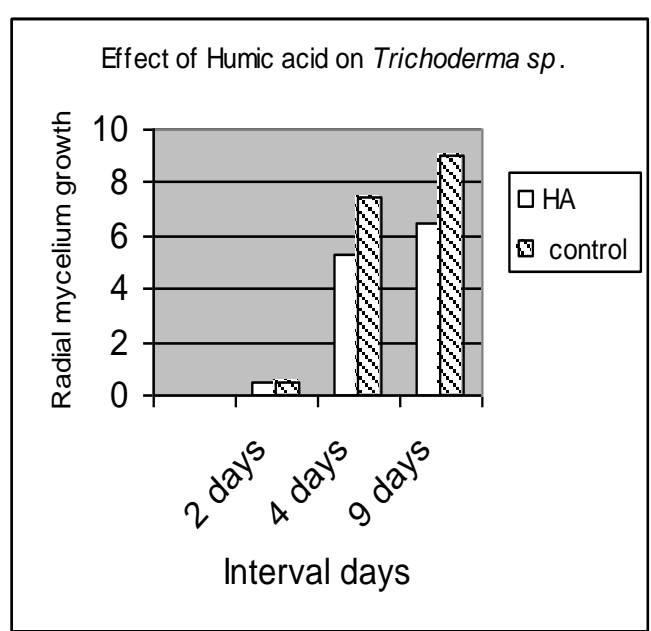

Figure 6. Effect of humic acid $(0.6 \%)$ on the radial mycelial growth of Trichoderma sp. (White bar) compared to the control (Dash bar).

3. Inhibitory effect of both humic acids and Trichoderma sp. on the radial mycelial growth of $S$. rolfsii :

Data in Table (4) show the inhibitory effect of Trichoderma sp. in presence of humic acid ( $0.6 \%$ concentration) on both isolates of $S$. rolfsii $(1,2)$. Trichoderma sp. in presence of humic acid completely overgrew the S. rolfsii (2) with percentage of inhibition $94.4 \%$ similar to the action of humic acid alone while the percentage of inhibition $53.3 \%$ in second isolate $S$. rolfsii (1) compared to action of humic acid alone (zero\%) as in Figures (7 and 8). 


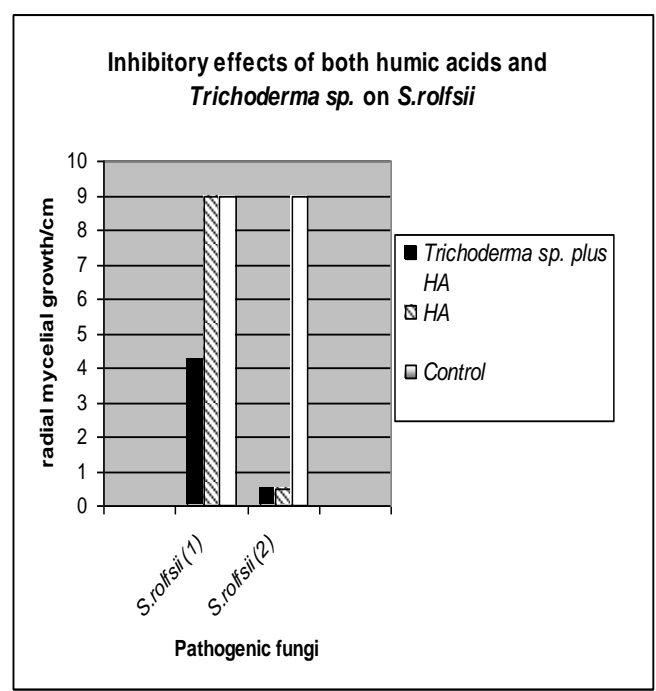

Figure 7. Inhibitory effect of both humic acids $(0.6 \%)$ and Trichoderma $s p$ on the radial mycelial growth of $S$. rolfsii $(1,2)$ compared to humic acid treatment and control.

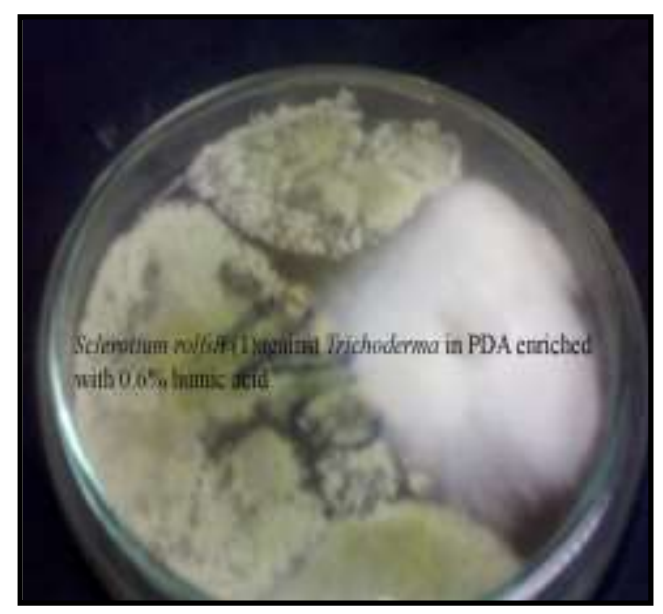

(A)

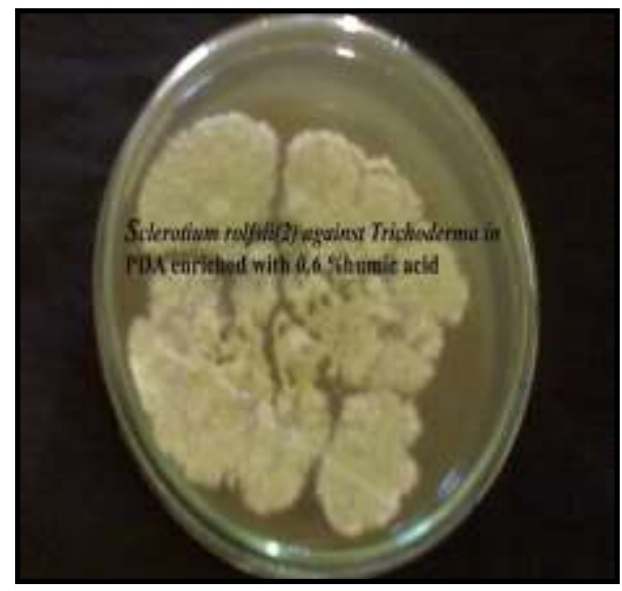

(B)

Figure 8. (A) The Inhibitory effects of both humic acids $(0.6 \%)$ and Trichoderma sp on the radial mycelial growth of $S$. rolfsii (1), (B) the Inhibitory effects of both humic acids $(0.6 \%)$ and Trichoderma sp on the radial mycelial growth of $S$. rolfsii (2). 
Table 4. Inhibitory effect of both humic acids (HA) and Trichoderma $s p$. on the radial mycelial growth of $S$. rolfsii $(1,2)$ after 9 days.

\begin{tabular}{|c|c|c|c|c|}
\hline $\begin{array}{c}\text { Radial mycelia } \\
\text { growth }^{*}(\mathrm{~cm})\end{array}$ & $\begin{array}{c}\text { Trichode } \\
\text { rma sp. } \\
\text { plus HA }\end{array}$ & $\begin{array}{c}\text { Percentage } \\
\text { of inhibition } \\
(\%)\end{array}$ & HA & $\begin{array}{c}\text { Percentage } \\
\text { of } \\
\text { inhibition } \\
(\%)\end{array}$ \\
\hline S. rolfsii (1) & 4.2 & 53.3 & 9 & Zero \\
\hline S. rolfsii (2) & 0.5 & 94.4 & 0.5 & 94.4 \\
\hline
\end{tabular}

(*) radial mycelial growth for each isolate of $S$. rolfsii alone (control) was $9 \mathrm{~cm}$

In agreement with this study, Bosah et al. (2010) proved that Trichoderma $s p$. was the most effective biocontrol agent against $S$. rolfsii with percentage of inhibition up to $81.36-80.29 \%$ at $6^{\text {th }}$ day of inoculation. The mechanism with which Trichoderma carries its antagonism may be mainly competition for nutrients and energy (Elad et al., 1980). Muhammad and Amusa (2003) elucidated that Trichoderma harzianum grew so fast on the mycelia of $S$. rolfsii. $T$. harzianum is known to produce extracellular cell wall degrading enzymes such as chitinases, $\beta-1,3-$ glucanases and cellulases which are important features of mycoparasites for the colonization of their host fungi (Lorito et al., 1994; Di Pietro, 1995).

\section{Conclusion}

In general, any HS treatment significantly reduced the radial growth of the $S$. rolfsii mycelium. Humic acid treatment was also able to alter the sclerotial production either by reducing significantly the number of viable germinating sclerotia or by increasing the number of sclerotia to double as a resistance mechanism towards the survival of $S$. rolfsii. In particular, the extent of the inhibitory action was related to some chemical and functional properties of HS, such as the $\mathrm{COOH}$ group content and elemental composition, appeared to be mainly control HS activity on fungi. No significant correlation between HS chemical properties and Trichoderma sp. 


\section{REFERENCES}

Abd-El-Karem, F., El-Mougy, N. S., El-Gamal, N. G., Fatouh, Y.O. 2006. Use of Chitin and Chitosan against Tomato Root Rot Disease under Greenhouse Conditions. Res. J. Agric. \& Biol. Sci., 2(4): 147-152.

Adani, F., Genevini, P., Tambone, F., Montoneri, E., 2006. Compost effect on soil humic acid: an NMR study. Chemosphere , 65: 1414-1418.

Ahmed, Y., M.S. Mirza and M. Aslam. 1984. Sclerotium rolfsii on maize. FAO Plant Prot. Bull., 32: 147.

Aycock, R. 1966. Stem rot and other diseases caused by Sclerotium rolfsii. NC. Agric. Exp. Sta. Tech. Bull, No. 174. 202pp.

Bosah, O., Igeleke, C.A., Omorusi, V.I., 2010. In Vitro Microbial Control of Pathogenic Sclerotium rolfsii. J. Agric. Biol., 12: 474-476.

Bowyer, P., 1999. Plant disease caused by fungi: phytopathogenicity In: Molecular Fungal Biology, (RP Oliver, M Schweizer), Cambridge University Press, Cambridge. Chapman and Hall, London, United Kingdom.

Chet, I., 1975. Ultrastructural basis of sclerotial survival in soil. Microbial Ecology, 2:194-200.

Di Pietro A (1995). Fungal antibiosis in biocontrol of plant diseases. Chapter 20 In: Allelopathy: Organisims, Processes and Applications. (Eds; Inderjit, Dakshini, K. M. M. and Einhellig, F. A). Pp. 271-279.

Elad, Y., I. Chet and J. katan, 1980. Trichoderma harzanium: A biological agent effective against Sclerotium rolfsii and Rhizoctonia solani. American Phytopathol. Soc., 70: 119-121.

Iqbal, S.M., A. Bakhsh, S. Hussain and B.A. Malik. 1995. Microbial antagonism against Sclerotium rolfsii, the cause of collar rot of lentil. Lens-Newsletter, 22: 48-49.

Jahangir, A.M., M.K. Mohibullah, M. Ayub and M. Khan. 1995. Detection of fungi causing root rot of apple nurseries in Swat. Sarhad J. Agri., 11: 754-748.

Loffredo, E., and Berloco, M., 2007. In vitro assessment of the inhibition of humic substances on the growth of two strains of Fusarium oxysporum. Biol. Fertil.Soils., 43:759-769.

Loffredo, E., Berloco, M., Senesi, N., 2008. The role of humic fractions from soil and compost in controlling the growth in vitro of phytopathogenic and antagonistic soil-borne fungi. Ecotoxicology and Environmental Safety, 69: 350-357. 
Lorito M., Hayes C. K., Di Pietro A., Woo S. L., Harman G. E. 1994. Purification, characterization and synergistic activity of a glucan $1,3 \beta$ glucosidase and $\mathrm{N}$-acetyl- $\beta$ glucosaminidase from Trichoderma harzianum. Phytopathology, 84: 394-405.

McMilian, R.T., Vande HEI, R.L., Graves, W.R. 1998. Southern blight (Sclerotium rolfsii): a new disease of cast iron plant. Proc. Fla. State Hort. Soc., 111:206-207.

Muhammad, S.and Amusa, N.A., 2003. In-vitro inhibition of growth of some seedling blight inducing pathogens by compost-inhabiting microbes. African Journal of Biotechnology, 2 (6), pp161-164.

Okereke, V.C. \& Wokocha, R.C., 2007. In vitro growth of four isolates of Sclerotium rolfsii sacc in the humid tropics. African Journal of Biotechnology, 6 (16), 1879-1881.

Pascual, J.A., Garcia, C., Hernandez, T., 1999. Comparison of fresh and composted organic waste in their efficacy for the improvement of arid soil quality. Bioresource Technol. 68, 255-264.

Punja, Z.K. 1985. Biology, ecology and control of Sclerotium rolfsii. Ann Rev Phytopathol., 23: 97-127.

Rolfs, P.H., 1892, Tomato blight. Some hints. Bulletin of Florida Agricultural Experimental Station, p. 18.

Ruqia, B. 2001. Studies on seed-borne mycoflora of sugarbeet (Beta vulgaris). M.Sc. Thesis, Department of Botany, University of Karachi, Karachi. $30 \mathrm{pp}$.

Shahzad, S. and A. Ghaffar. 1995. New records of soilborne root infecting fungi in Pakistan. Pak. J. Bot., 17: 209-216. 
تأثير المواد الابالية على نمو فطر السكلورشيوم ولفساي وفظر المقاومة الحيوية التموية التريكوردرما

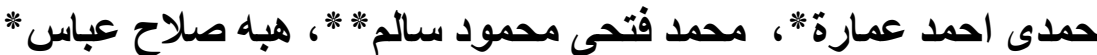

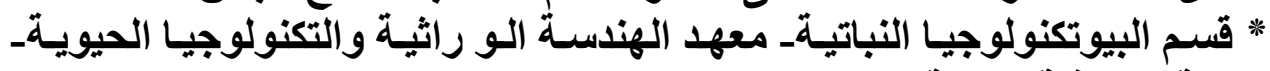

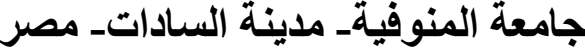

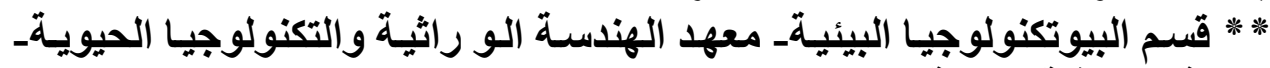
جامعة المنوفيةـ مدينة الساداتـ مصر الئية

تم تقييم تأثير المو اد الدبالية المعزولة من الكمبوست على نمو سلالتين لفطر

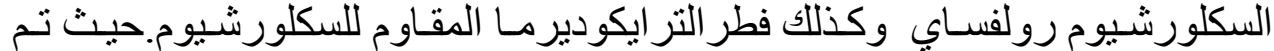

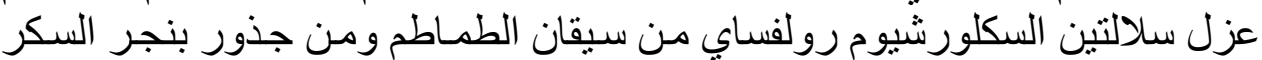

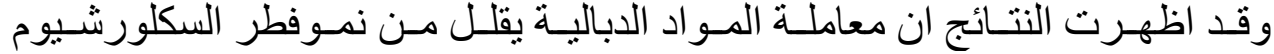

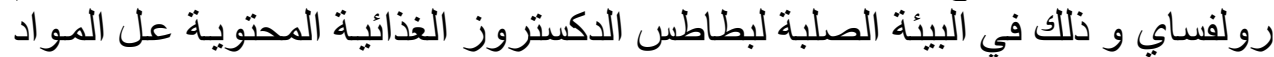

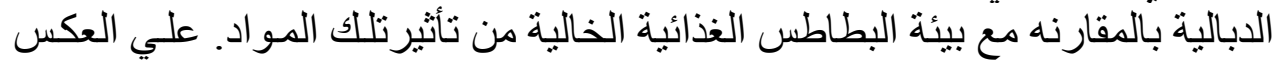

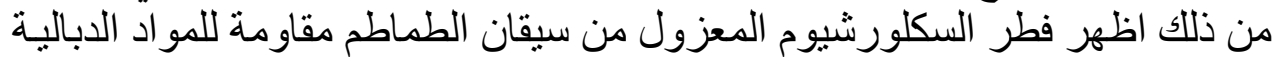

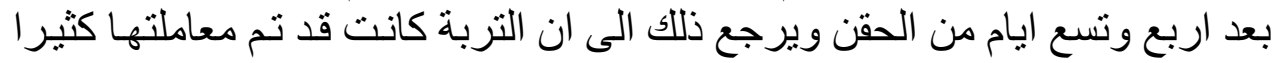

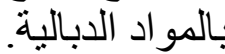

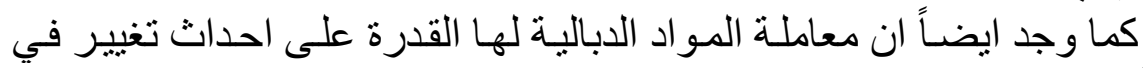

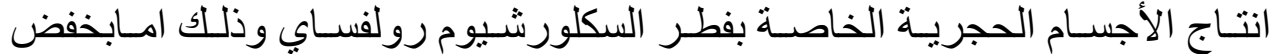

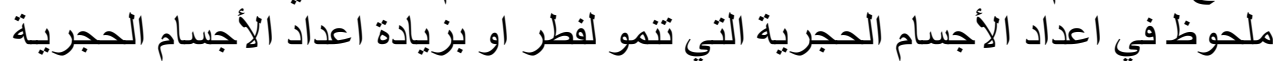

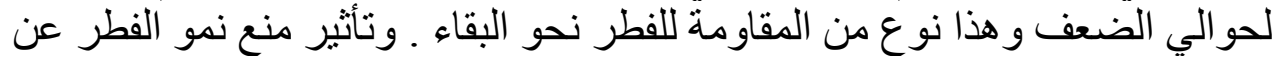

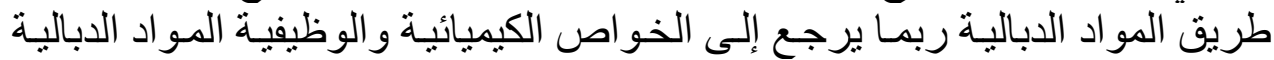

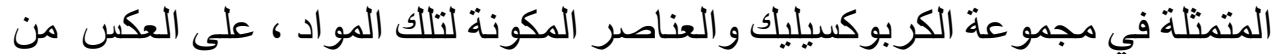

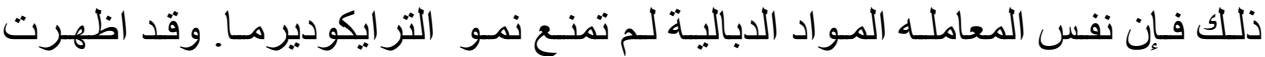

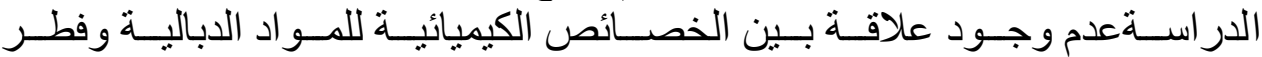

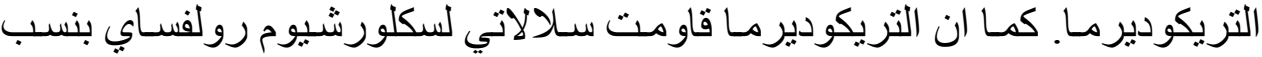

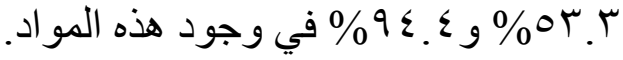

